\title{
Ecological Studies on Aphid Species Infesting Main cereal Crops
}

\author{
EL-Khayat, E. F."; Aziza M. EL-Gantiry"*; Rasha A. EL-Hosserey" and S. A. Amer** \\ * Plant Protection Department, Faculty of Agriculture, Benha University, Egypt \\ ** Plant Protection Research Institute, Agricultural Research Center, Giza, Egypt \\ Corresponding author: abosamdy2010@yahoo.com
}

\begin{abstract}
The present work was conducted during 2012/2013 and 2013/2014 seasons to survey aphid species infesting maize, wheat and barley at Abo-Hammad district, Sharkia Governorate, Egypt. Effects of some climatic factors on population of the dominant aphid species were also studied. The aphids, Rhopalosiphum maidis (Fitch), Rhopalosiphum padi (L.), Schizaphis graminum (Rond.) and Sitobion avenae (F.) were collected from wheat and barley plants, while R. maidis (Fitch), R. padi (L.) and Aphis gossypii (Glov.) were collected from maize plants. Plant sample proved to be efficient method to collect and survey aphid species during the two successive seasons of investigation. Regarding the seasonal abundance on maize, $R$. maidis (Fitch) recorded one peak at the $2^{\text {nd }}$ week of August in both seasons 2012 and 2013 (1640 and 1250 individuals/sample, respectively), also $R$. padi (L.) and A. gossypii (Glov.) had one peak in the $3^{\text {rd }}$ week of August in 2012 and 2013 seasons (978 \& 95 and $815 \& 91$ individuals/sample, respectively). On wheat, $R$. padi (L.) and $R$. maidis (Fitch) were represented by one peak at the last week of February in 2012/2013 and 2013/2014 seasons (320 \& 285 and $450 \& 266$ individuals/sample, respectively), while S. graminum (Rond.) recorded one peak on the first week of March in 2012/2103 and 2013/2014 seasons (87 and 79 individuals/sample, respectively). S. avenae (F.) recorded one peak on the $2^{\text {nd }}$ week of April in both studies seasons (199 and 710 individuals/sample, respectively). On barley, $R$. padi (L.) was represented by one peak at the third week of February in 2012/2013 and 2013/2014 seasons (238 \& 271 individuals/sample, respectively) but the only peak of $R$. maidis (Fitch) was at the third and fourth week of February in 2012/2013 and 2013/2014 seasons (246 \& 174 individuals/sample), respectively. $S$. graminum (Rond.) recorded one peak on the $3^{\text {rd }}$ and $4^{\text {th }}$ week of February in 2012/2103 and 2013/2014 seasons (34 and 35 individuals/sample), respectively. The results indicated that the tested meteorological factors play a great role in regulating the population density and seasonal abundance of these aphid species.
\end{abstract}

Keywords: Maize, Wheat, Barley, aphids, Climatic Factors

\section{Introduction}

Maize (Zea mays L.), Wheat (Triticum aestivum L.) and barley (Hardeum vulgare L.) are considered the most important crops used as human food in Egypt. As a result of the expansion of cultivated graminaceous crops the problems of insect pests have been increased in the last years subjected to attack by a large number of insect pests throughout the growing seasons, Hashem, (2005). Aphids cause serious damage either directly by sucking plant juice or indirectly as vectors of virus diseases (Hashem, 1997 and Abd- Elsamed, 2006).

The aphid species, Rhopalosiphun padi (L.), Schizaphis graminum (Rond.), R. maidis (Fitch), Sitobion avenae (F.) and A. gossypii infested maize and wheat plants in Egypt, Abou El-Hagag and Abdel-Hafez, (1998); Hegab, (2001) and AbdElsamed, (2006); in Kenya, Wangal et al., (2000); in Pakistan, Akhtar, (2002); in USA, Hadi et al., (2011) and in Iran, Nassab et al., (2013)\}. They found that the average daily temperature and relative humidity played important role in controlling aphid populations in wheat and maize fields. Aphid density peaked on wheat in the end of February (Akhtar,
2002 in Pakistan). Also, in Pakistan, aphid individuals appeared on all cultivars/lines at the $3^{\text {rd }}$ week of January and reached its peak on the middle of March on all the cultivars/lines and totally eliminated at the $1^{\text {st }}$ week of April (Muhammad $\boldsymbol{e t}$ al., 2004). In Egypt, $R$. maidis and $R$. padi peaked at the mid of August and at the first week of March on maize and wheat plants, respectively, while $S$. graminum (on wheat) and $A$. gossypii (on maize) was represented at mid of March and at the third week of August, respectively (Abd-Elsamed, 2006).

The present study is contributed towards a better knowledge about dominant aphid species infesting maize, wheat and barley crops, the efficiency of the different sampling techniques and effects of certain climatic factors on the population density of these aphid species.

\section{Material and methods}

Ecological studies on the important common aphid species were carried out at Abo-Hammad district, Sharkia Governorate. The area of experiments $\left(1450 \mathrm{~m}^{2}\right)$ planted with maize, wheat and barley plants during the two successive seasons 2012/ 
2013 and 2013/ 2014. The experimental area was divided into nine equal plots. Each crop has been represented by three replicates (plots). Randomized Complete Block design was the used design in all growing seasons of maize, wheat and barley.

Date of maize sowing was in the $2^{\text {nd }}$ week of May 2012 and 2013 seasons, while wheat and barley sowing dates were at the mid of November in both seasons (2012/2013 and 2013/2014). Normal agricultural practices were timely followed. Sampling started when the age of maize, wheat and barley plants reached about 21 days and continued at weekly intervals throughout the period of growth until the end of September for maize and the first week of May for wheat and barley.

Two sampling methods were used to survey the aphid species infesting maize, wheat and barley plants:-

\section{1- Plant samples}

Weekly maize samples of 10 leaves and 5 tassels were taken randomly from 5 plants, whereas the weekly wheat and barley samples were 25 tillers. The infested leaves and tassels were kept in paper bags .The samples were examined in the laboratory and the number of individuals of alatae, apterous and nymphs were separately counted and recorded by using a hand lens $(5 \mathrm{X})$. A simple apparatus was used for this purpose, which consistes of a wooden desk, a white card board paper divided into $4 \mathrm{~cm}$. A part column put in the bottom on which a glass plate was placed and the upper surface of the glass plate was allowed to be wet with fine droplets of water to reduce the movement of counted aphid, (Hegab et al., 1987). The plants were carefully shaken on the plate and the aphid insects were counted using a small brush in each column. The aphid species were preserved in $90 \%$ ethyl-alcohol and identified according to Habib and El-kady, (1961) and Blackman and Eastop, (2000).

\section{2-Yellow sticky board traps}

Three yellow sticky board traps were used for each crop in this experiment. The weekly counts of captured aphid species were counted and recorded for each trap. The aphid species were identified according to Habib and El-kady, (1961) and Blackman and Eastop, (2000).

The daily recorded of both maximum and minimum temperature degrees along with relative humidity during 2012/2013 and 2013/2014 seasons were obtained from the Agrometeorological station at Zagazig city.

The relationship between the weekly mean numbers of collected aphid species and the corresponding weekly means of maximum, minimum temperatures and relative humidity were estimated. Partial regression was applied to show the effect of each factor on the population density of the aphid species under investigation.
The obtained results were statistically analyzed; correlation coefficient, explained variances and partial regression values were estimated according to Costat, (1990).

\section{Results and Discussion}

\section{Survey of aphid species on maize, wheat and barley plants}

In the present work, five aphid species were surveyed by two methods of collection (Plant samples and yellow sticky board traps) on maize, wheat and barley (Table, 1):

1) Corn leaf aphid, Rhopalosiphum maidis (Fitch)

2) Bird cherry-oat aphid, Rhopalosiphum padi (L.)

3) Greenbug, Schizaphis graminum (Rond.)

4) English grain aphid, Sitobion avenae (F.)

5) Cotton aphid, Aphis gossypii (Glover)

Plant sample and yellow sticky board traps were effective to survey aphid species during 2012/2013 and 2013/2014, but the plant sample is more efficient. These results agreed with those of Hegab et al., (1987), who mentioned that yellow sticky board and plant sample seemed to be the most efficient to evaluate aphid species in maize and wheat fields in newly reclaimed sandy areas. They collected $A$. gossypii from maize crop only. Abd-El-samed, (1999 and 2006) mentioned that sticky trap is one of the best sampling methods available for estimating winged aphids population in wheat and maize fields, therefore sticky traps could be used to determine the relative winged aphid density.

The most extensive infestation by $R$. maidis (F.) was recorded on maize plants, followed by wheat and barley plants. Concerning the total number of $S$. avenae (Fabr.), it was found that $S$. avenae was rarely existence on barley. In the first season, the population on wheat plants was about 9 folds the population on the barley, but it recorded around 40 folds in the second season.

\section{Seasonal abundance of aphid species on maize, wheat and barley plants \\ 1-Maize}

a. The corn leaf aphid, Rhopalosiphum maidis (Fitch)

During both seasons the corn leaf aphid were found during the period from the $1^{\text {st }}$ week of July to the $3^{\text {rd }}$ week of September. The mean numbers of aphid collected from maize plants during 2012 and 2013 seasons were graphically illustrated in Figs., (1, 2 ). The highest population density of $R$. maidis individuals occurred in the $2^{\text {nd }}$ week of August with a total number, 1640 and 1250 individuals/sample in 2012 and 2013 seasons, respectively at mean temperature of $31.79{ }^{\circ} \mathrm{C}$ with $44.79 \%$ R.H. and 29.00 ${ }^{\circ} \mathrm{C}$ with $50.36 \%$ R.H. for the two seasons, respectively. The population of $R$. maidis was greater 
in the first season (approximately 1.5 folds) than in the second season (Table, 1).

\section{b. The bird cherry-oat aphid, Rhopalosiphum padi} (L.)

The first sample of $R$. padi were collected in the mid of July from maize plants during the two seasons (2012 and 2013). The mean numbers of aphid, $R$. padi infesting maize plants were graphically illustrated in Figs., $(1,2)$. The obtained data show one peak of $R$. padi activity on maize plants in the $3^{\text {rd }}$ week of August with a total number of 978 and 815 individuals/sample in 2012 and 2013 seasons, respectively at mean temperature of $29.64{ }^{\circ} \mathrm{C}$ with $50.71 \%$ R.H. and $29.00{ }^{\circ} \mathrm{C}$ with $56.08 \%$ R.H. for the two seasons, respectively. Regarding the weekly counts of $R$. padi, it is clear that this species

Table 1. Total number of aphid species infesting main cereal crops at Abo-Hammad, Sharkia Governorate collected by using plant sample and yellow sticky board traps during 2012/2013 and 2013/2014 seasons

\begin{tabular}{llcccc}
\hline \multirow{2}{*}{ Aphid Species } & Cereal & \multicolumn{3}{c}{ Total no. of aphids collected by } \\
\cline { 3 - 6 } & Crops & \multicolumn{2}{c}{ Plant sample } & yellow sticky board traps \\
\cline { 3 - 6 } & & $\mathbf{2 0 1 2 / 2 0 1 3}$ & $\mathbf{2 0 1 3 / 2 0 1 4}$ & $\mathbf{2 0 1 2 / 2 0 1 3}$ & $\mathbf{2 0 1 3 / 2 0 1 4}$ \\
\hline \multirow{3}{*}{ Rhopalosiphum maidis } & Maize & 20791 & 14173 & 1300 & 1061 \\
& Wheat & 3899 & 4267 & 615 & 647 \\
& Barley & 3362 & 3643 & 426 & 418 \\
Rhopalosiphum padi & Maize & 10547 & 8710 & 1215 & 883 \\
& Wheat & 7937 & 8611 & 1058 & 1170 \\
Sitobion avenae & Barley & 3617 & 3832 & 811 & 625 \\
& Wheat & 801 & 5465 & 88 & 1359 \\
Schizaphis graminum & Barley & 88 & 136 & 14 & 29 \\
\multirow{2}{*}{ Aphis gossypii } & Wheat & 1571 & 1764 & 144 & 94 \\
\hline
\end{tabular}
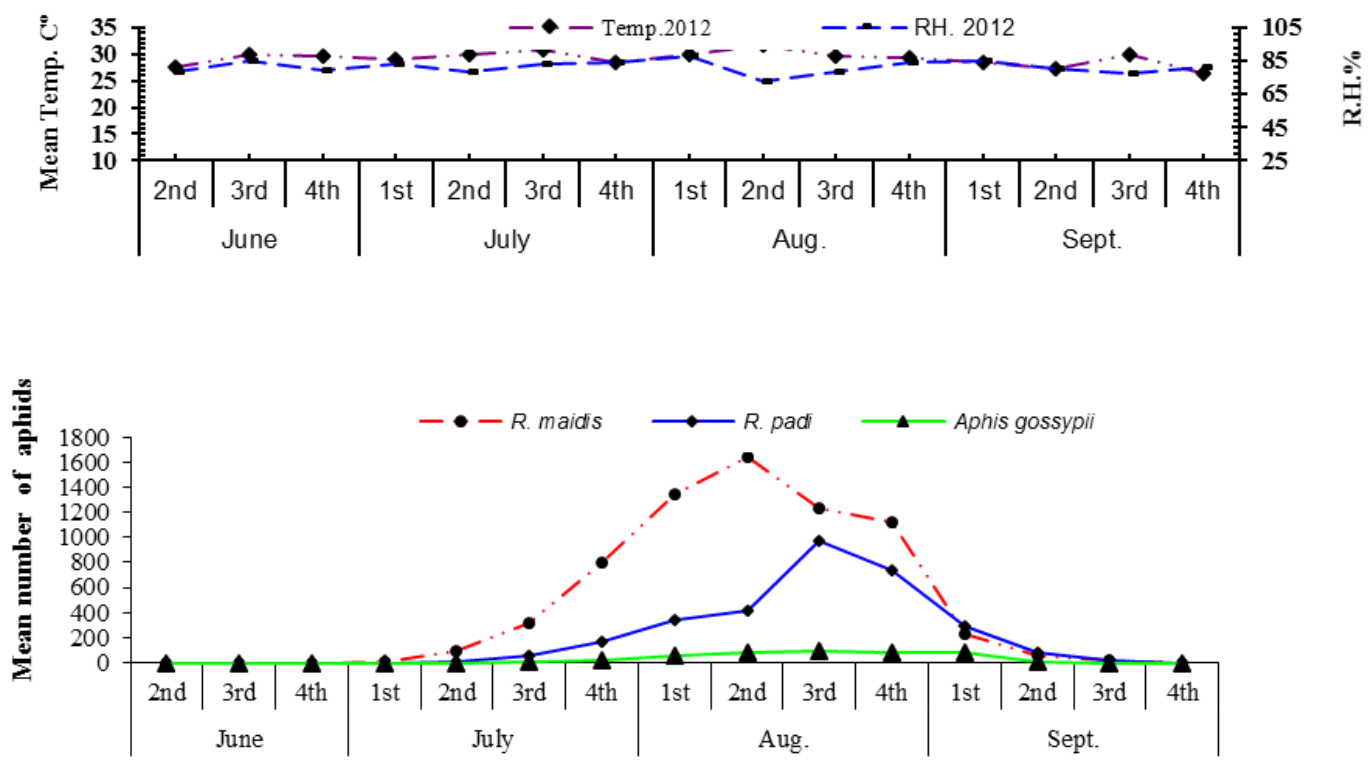

weekly date of maize sample 2012

Fig. 1: Population density of aphids infesting maize plants at Abo - Hammad, Sharkia Governorate during 2012. 

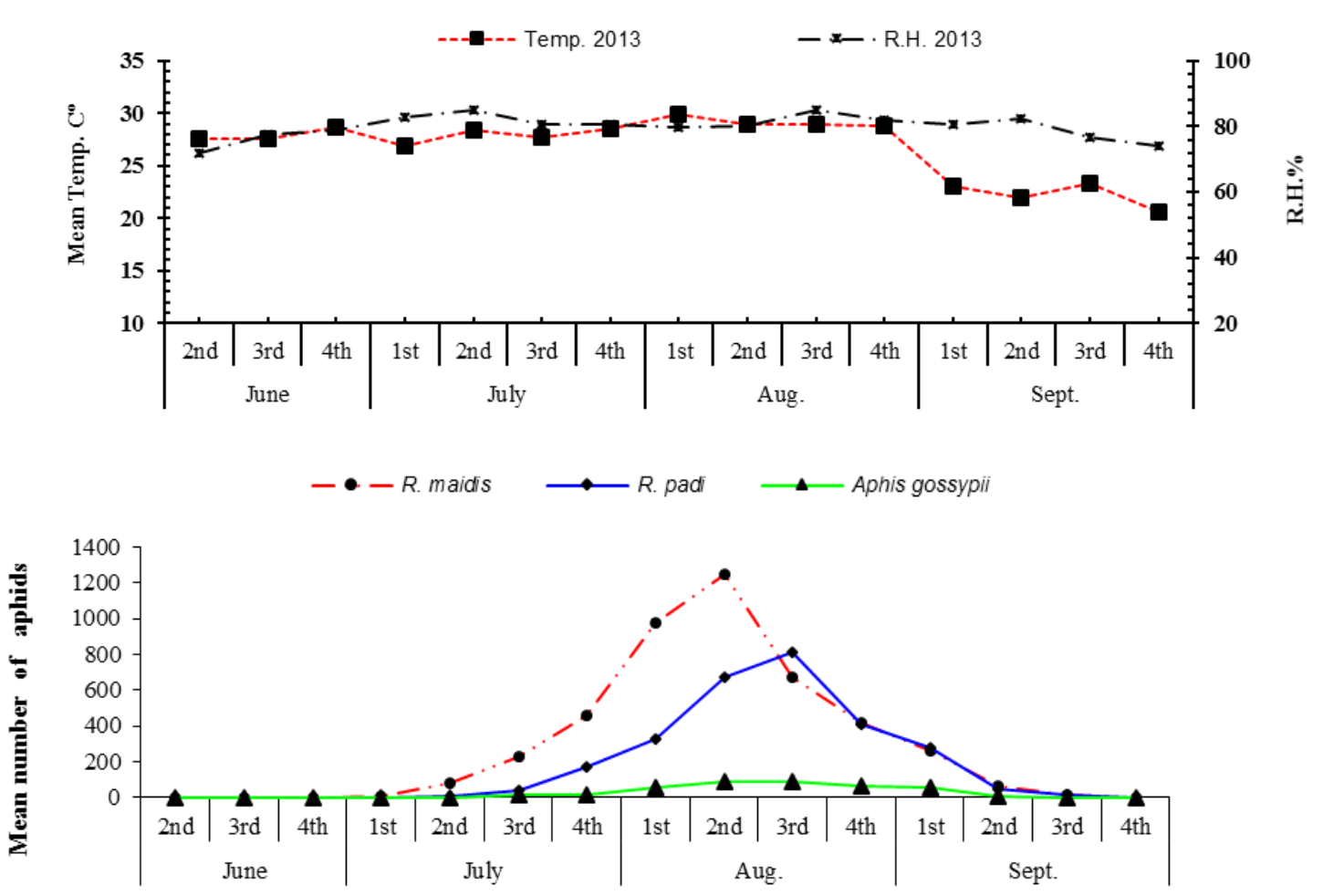

weekly date of maize sample 2013

Fig. 2: Population density of aphids infesting maize plants at Abo - Hammad, Sharkia Governorate during 2013.

was 1.2 folds in 2013 more than in 2012 (Table, 1). The population of $R$. maidis was about twice and 1.6 $R$. padi population in the first and second seasons, respectively (Table, 1 ).

\section{c. The cotton aphid, Aphis gossypii (Glover)}

The cotton aphid was found for the first time in the $3^{\text {rd }}$ week of July (2012 and 2013 seasons). The mean numbers of $A$. gossypii collected from maize by plant sample during 2012 and 2013 seasons were graphically represented in Figs., 1, 2. The mean number of A. gossypii on maize plants increased until it reached its peak in the $3^{\text {rd }}$ week of August of 95 and 91 individuals/ sample in 2012 and 2013 seasons, respectively at mean temperature of $29.64^{\circ} \mathrm{C}$ with $50.71 \%$ R.H. and $29.00^{\circ} \mathrm{C}$ with $56.08 \%$ R.H. for the two seasons, respectively. Generally, the weekly counts of A. gossypii on maize plants appeared that the population during 2012 equal 1.2 folds in 2013 season (Table, 1). The cotton aphid was the least aphid population on maize. In the first season, $R$. maidis and $R$. padi populations more 16 and 8 folds than $A$. gossypii population, but during the second season $R$. maidis and $R$. padi populations more 13 and 8 folds than $A$. gossypii population.

Results in general concerning the population density of $R$. padi, R. maidis and A. gossypii on cereal crops showed clearly that these species have one peak on maize plants. This result agreed with the findings of Abd-Alla, (1985) and Abd-Elsamed, (1999 and 2006), who showed that the activity of $R$. maidis, $R$. padi and A. gossypii have one peak on maize plants during summer plantation.

\section{Wheat}

a. The bird cherry-oat aphid, Rhopalosiphum padi (L.)

In both seasoans, the bird cherry-oat aphid occurred in early December to the end of April. The mean numbers of $R$. padi on wheat plants during $2012 / 2013$ and 2013/2014 seasons by plant samples were graphically represented in Figs., $(3,4)$. The mean numbers of $R$. padi on wheat plants increased until it reached the peak at the end of February of 320 and 450 individuals/sample in 2012/2013 and $2013 / 2014$ seasons, respectively at mean temperature of $18.43{ }^{\circ} \mathrm{C}$ with $50.57 \%$ R.H. and $16.90{ }^{\circ} \mathrm{C}$ with $57.00 \%$ R.H. for the two seasons, respectively. In both seasons, the population of $R$. padi was almost equal, but it was on a par with double the population of $R$. maidis (Table, 1). The population of $R$. padi on maize greater (1.3 folds) than on wheat during the first season, while they were around equal in the second.

\section{b. The corn leaf aphid, Rhopalosiphum maidis (Fitch)}

During the two seasons of study, the corn leaf aphid existed from the $3^{\text {rd }}$ week of December to the $3^{\text {rd }}$ week of April. The mean numbers of $R$. maidis collected 

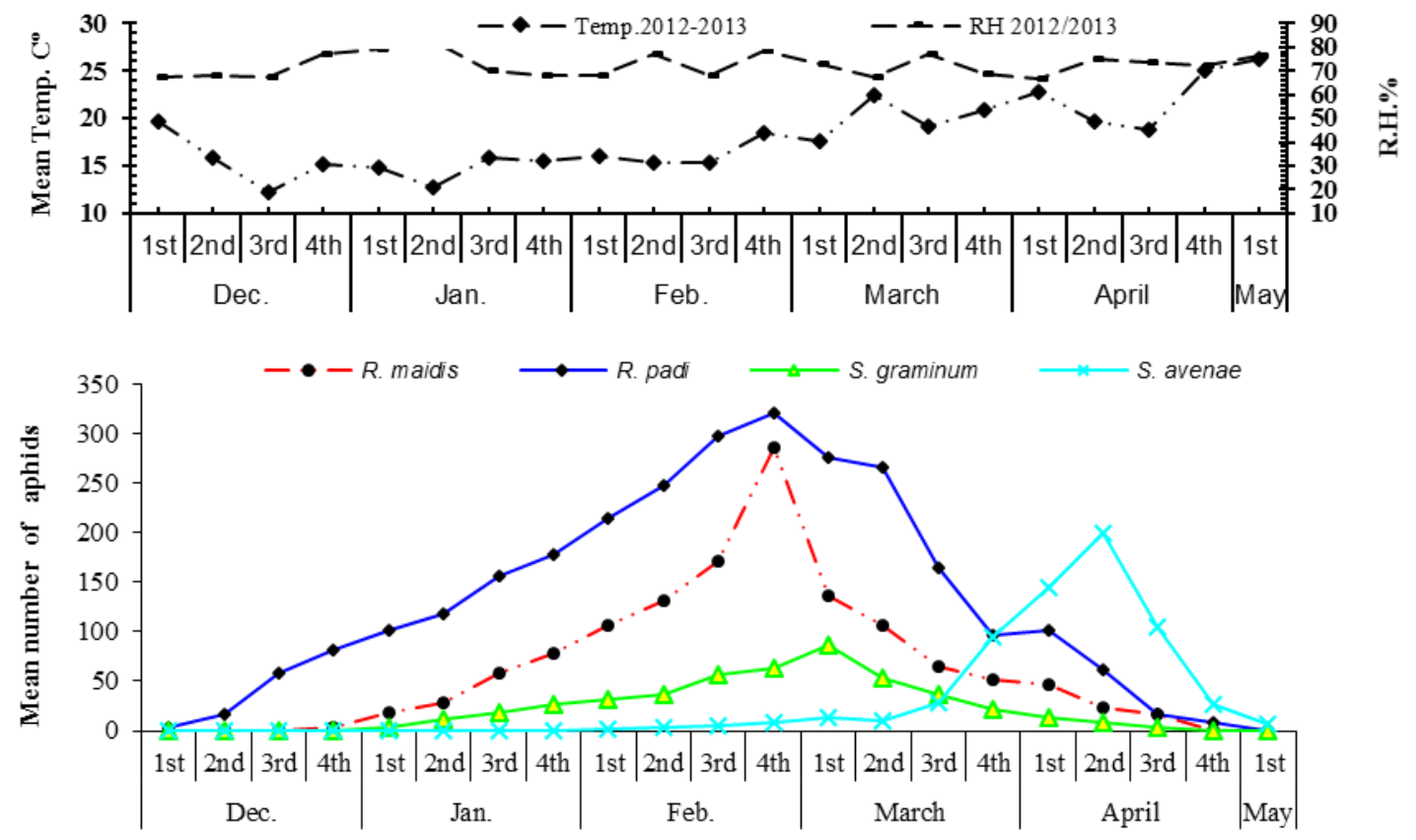

weekly date of wheat sample 2012/2013

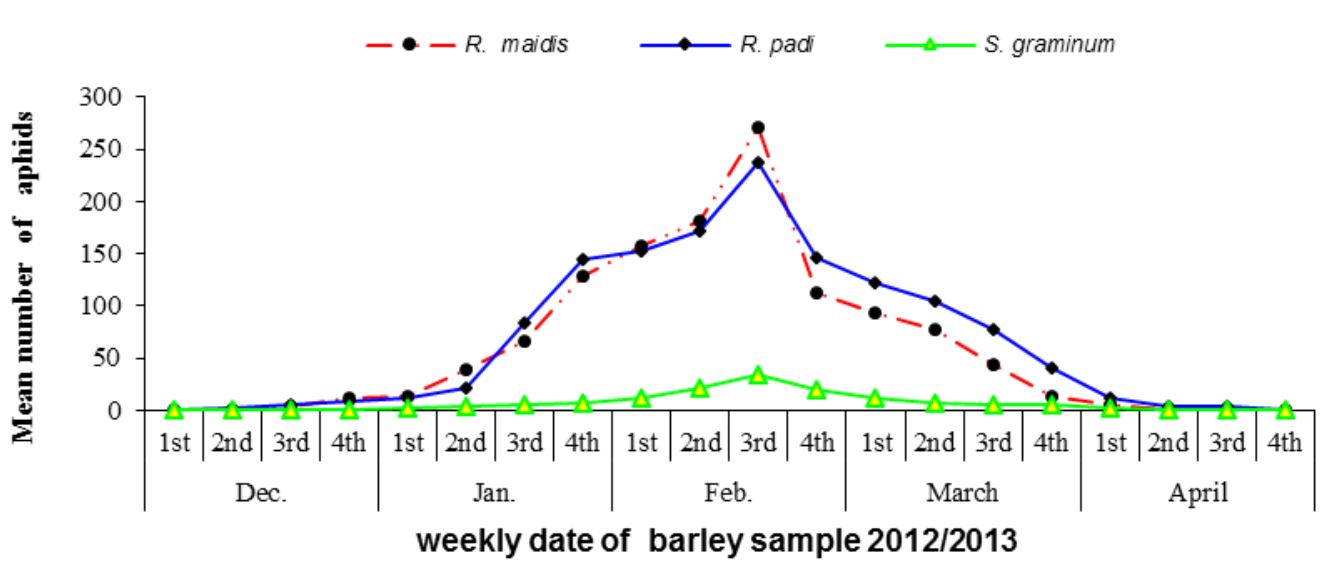

Fig. 3. Population density of aphids infesting wheat and barley plants at Abo - Hammad, Sharkia Governorate during 2012/2013 season.

From wheat plants during the both seasons, using plant samples were graphically illustrated in Figs., $(3,4)$. One peak occurred at the end of February with a total number, 285 and 266 individuals/sample at mean temperature of $18.43{ }^{\circ} \mathrm{C}$ with $50.57 \%$ R.H. and $16.90{ }^{\circ} \mathrm{C}$ with $57.00 \%$ R.H. for the two seasons, respectively (Figs. 3, 4). The population of R. maidis on maize plants recorded 5 and 3 folds more than on wheat plants during 2012/2013 and 2013/2014, respectively.

\section{c. The greenbug, Schizaphis graminum (Rond.)}

The greenbug was found during the period from the $4^{\text {th }}$ week of December to the $3^{\text {rd }}$ week of April along both study seasons. The weekly mean numbers of $S$. graminum on wheat plants during 2012/2013 and 2013/2014 seasons were graphically illustrated in Figs., $(3,4)$. The number of individuals fluctuated on wheat plants with general increase reaching its peak. One peak only occurred at the $1^{\text {st }}$ of March during 2012/2013 and 2013/2014 seasons with a total number of 87 and 79 individuals /sample at mean temperature of $17.57{ }^{\circ} \mathrm{C}$ with $47.50 \%$ R.H. and 21.00 ${ }^{\circ} \mathrm{C}$ with $56.29 \%$ R.H. for the two seasons, respectively. Regarding the weekly counts of $S$. graminum on wheat plants, it was nearly equivalent during 2012/2013 and 2013/2014 seasons.

\section{d. English grain aphid, Sitobion avenae $(\mathrm{F}$.}

From the $1^{\text {st }}$ and $2^{\text {nd }}$ week of February to early May, the English grain aphid existed in the first and second seasons, respectively. The weekly mean numbers of $S$. avenae on wheat plant during 2012/2013 and 2013/2014 seasons were graphically illustrated in Figs., $(3,4)$. The number of individuals fluctuated and increased gradually to reach its peak. This peak occurred during 2012/2013 and 2013/2014 seasons at the mid of April with a total number of 
199 and 710 individuals/sample at mean temperature of $19.57^{\circ} \mathrm{C}$ with $48.79 \%$ R.H. and $23.60^{\circ} \mathrm{C}$ with $45.57 \%$ R.H. for the two seasons (Figs., 3, 4), respectively. Regarding the weekly counts of $S$. avenae on wheat plants, it was evaluated around 7 folds during 2013/2014 compared with the population during 2012/2013.

According to the obtained results on the population density of $R$. padi, R. maidis and $S$. graminum, it is obvious that these species had one peak on wheat plants. These results agreed with the findings of Hegab, (1997 and 2001) and AbdElsamed, (2006), who showed that the activity of $R$. maidis, $R$. padi and $S$. graminum had one peak on wheat plants during winter plantation.

\section{Barley}

a. The bird cherry-oat aphid, Rhopalosiphum padi
In both seasons, the bird cherry-oat aphid occurred in the second week of December to the mid of April. The mean number of $R$. padi counted on barley during 2012/2013 and 2013/2014 seasons by using plant samples are graphically represented in Figs., $(3,4)$. Population of $R$. padi on barley plants increased until it reached the peak at the $3^{\text {rd }}$ week of February with a mean number of 238 and 246 individuals/sample in 2012/2013 and 2013/2014 seasons, respectively at mean temperature $15.43^{\circ} \mathrm{C}$ with $44.93 \%$ R.H. and $15.70^{\circ} \mathrm{C}$ with $68.00 \%$ R.H. for the two seasons, respectively (Figs., $3 \& 4$ ). The population of $R$. padi on barley plants approximately had no changes during both seasons, whereas it was greater on wheat (about 2.0 and 2.3 folds during the first and second seasons, respectively) than on barley plants.

\section{(L.)}
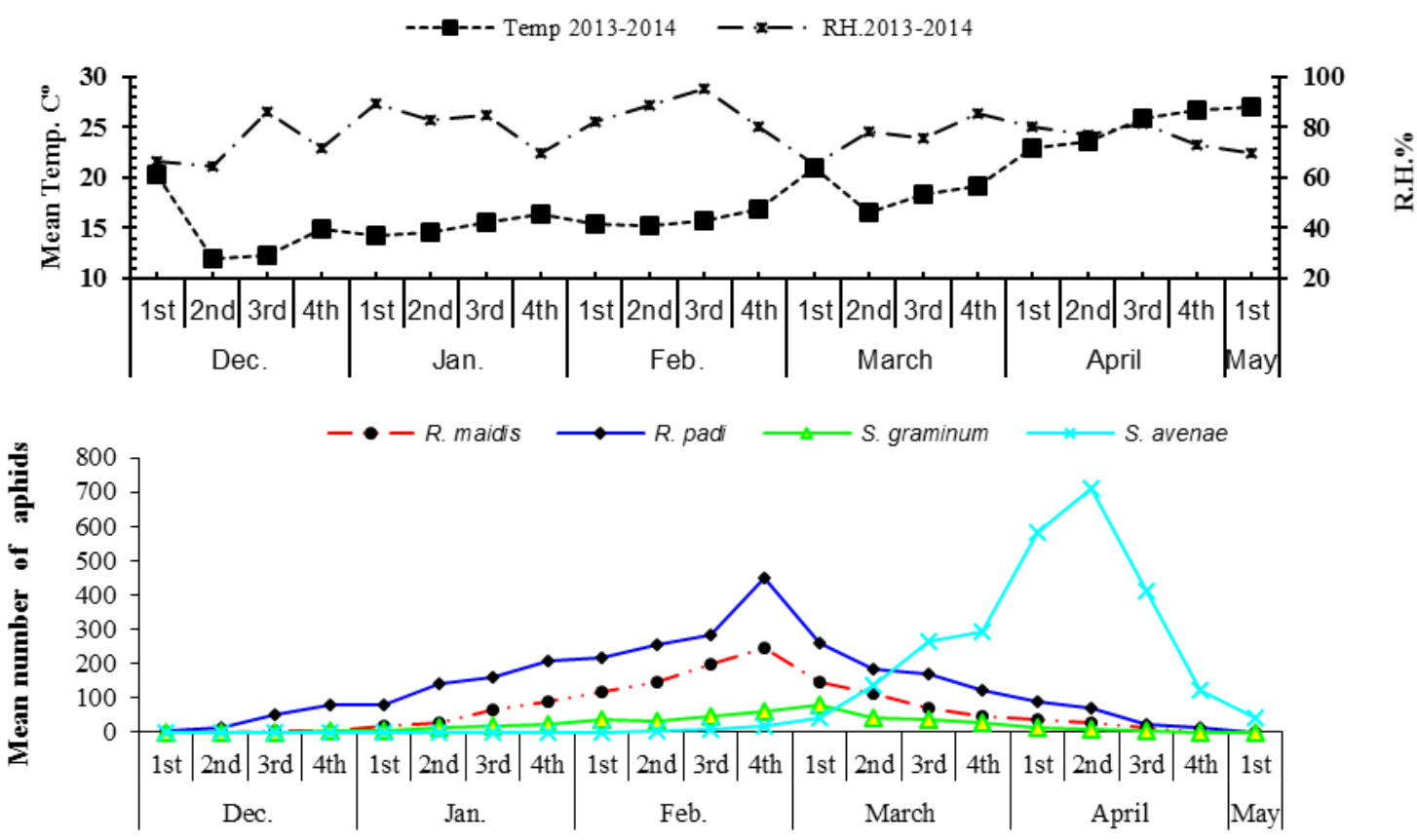

weekly date of wheat sample 2013/2014

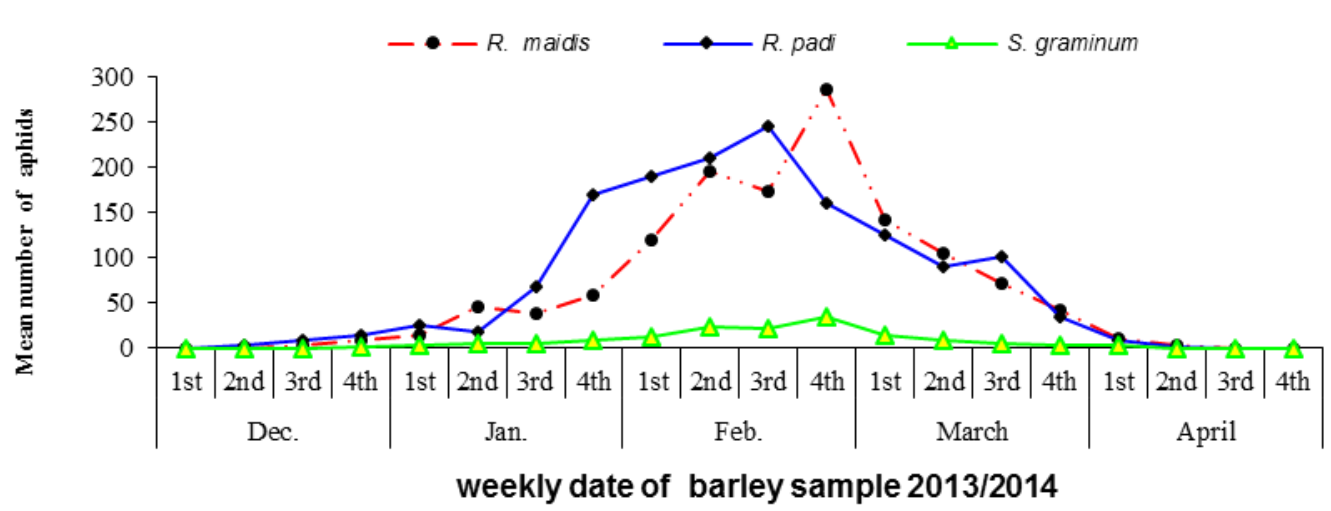

Fig. 4: Population density of aphids infesting wheat and barley plants at Abo - Hammad, Sharkia Governorate during 2013/2014 season. 


\section{b. The corn leaf aphid, Rhopalosiphum maidis (Fitch)}

During the two seasons of study, the corn leaf aphid existed from the $3^{\text {rd }}$ week of December to the $1^{\text {st }}$ week of April. The mean numbers of $R$. maidis collected from barley plants during 2012/2013 and 2013/2014 seasons using plant samples are graphically illustrated in Figs., $(3,4)$. One peak on barley plants occurred in the $3^{\text {rd }}$ week of February with a total number 271 and 285 individuals/sample at mean temperature of $15.43{ }^{\circ} \mathrm{C}$ with, $44.93 \%$ R.H. and $15.70^{\circ} \mathrm{C}$ with $68.00 \%$ R.H. during $2012 / 2013$ and 2013/2014 seasons, respectively (Figs. 3, 4). In the second season, the population of $R$. maidis on barley increased slightly, but it was equal with the population on wheat during the both seasons.

\section{c. The greenbug, Schizaphis graminum (Rond.)}

The greenbug was found during the period from the $4^{\text {th }}$ week of December to the $1^{\text {st }}$ week of April along both study seasons. The weekly mean numbers of $S$. graminum collected from barley plants during 2012/2013 and 2013/2014 seasons were graphically illustrated in Figs., (3, 4). The number of individuals fluctuated and increased reaching its peak (Figs., $3 \& 4$ ). The only .peak occurred at the $3^{\text {rd }}$ and $4^{\text {th }}$ week of February with a total number of 34 and 35 individuals/sample at mean temperature of $15.43^{\circ} \mathrm{C}$ with $44.93 \%$ R.H. and $15.70{ }^{\circ} \mathrm{C}$ with 68.00 $\%$ R.H. in the 2012/2013 and 2013/2014 seasons, respectively. Regarding the weekly counts of $S$. graminum on barley plants, the population was little more during 2012/2013 (1.3 fold) than during 2013/2014. In the first season, the population of $S$. graminum on the wheat was 2.7 folds its population on the barley, but it recorded 4.0 folds in the second season.

III. Effect of certain climatic factors, (maximum temperature, minimum temperature and mean relative humidity) on the population of the dominant aphid species infesting maize, wheat and barley plants.

\section{The corn leaf aphid, Rhopalosiphum maidis (Fitch)}

The correlation coefficient between activity of $R$. maidis population and maximum temperature $\left(\mathrm{r}_{1}\right)$, minimum temperature $\left(\mathrm{r}_{2}\right)$ or relative humidity $\left(\mathrm{r}_{3}\right)$ was positive and insignificant $\left(r_{1}=0.3140 \& 0.3130\right.$, $r_{2}=0.2549 \& 0.3070$ and $r_{3}=0.3162 \& 0.3033$ in $2012 / 2013$ and 203/2014 seasons, respectively). The partial regression between $R$. maidis population activity and maximum temperature $\left(b_{1}\right)$, minimum temperature $\left(b_{2}\right)$ or relative humidity $\left(b_{3}\right)$ was positive and insignificant $\left(b_{1}=2.5980 \& 3.6450, b_{2}=\right.$ $5.4720 \& 4.1728$ and $b_{3}=0.0021 \& 0.3750$ in $2012 / 2013$ and 203/2014 seasons, respectively) (Table, 2).

\section{The bird cherry-oat aphid, Rhopalosiphum} padi (L.)

The results obtained in Table, (2) reveal that the correlation coefficient between $R$. padi population and maximum temperature was positive insignificant $\left(r_{1}=0.3156\right)$ in $2012 / 2013$ but positive and significant $\left(r_{1}=0.5630^{*}\right)$ in $2013 / 2014$ seasons. The numbers of $R$. padi correlated positively and significantly with minimum temperature $\left(\mathrm{r}_{2}=0.5769^{*}\right.$ and $0.5114^{*}$ ) in 2012/2013 and 2013/2014 seasons, respectively. The correlation between $R$. padi population and relative humidity was positive and insignificant $\left(\mathrm{r}_{3}=0.3162\right.$ and 0.3071 in 2012/2013 and 2013/2014 seasons, respectively). The partial regression between $R$. padi population and maximum temperature $\left(b_{1}\right)$, minimum temperature $\left(b_{2}\right)$ or relative humidity $\left(b_{3}\right)$ was positive and insignificant $\left(b_{1}=0.0015 \& 0.0023, b_{2}=0.0021 \& 0.0014\right.$ and $b_{3}$ $=0.0037 \& 0.0042 \mathrm{in} 2012 / 2013$ and 2013/2014 seasons, respectively), Table, (2).

\section{The greenbug, Schizaphis graminum (Rond.)}

The mean numbers of $S$. graminum population had positive and insignificant correlation with maximum temperature $\left(r_{1}=0.2638\right.$ and 0.2661$)$ and relative humidity $\left(\mathrm{r}_{3}=0.2651\right.$ and 0.2657$)$ in $2012 / 2013$ and 2013/2014 seasons, respectively, it was positive and insignificant $\left(\mathrm{r}_{2}=0.2672\right)$ with minimum temperature in 2012/2013 and negative and insignificant $\left(\mathrm{r}_{2}=-0.0941\right)$ in $2013 / 2014$ season. The same trend was recorded with the partial regression between $S$. graminum population and maximum temperature $\left(b_{1}=0.0302\right.$ and 0.0264$)$, minimum temperature $\left(b_{2}=0.0182\right.$ and -0.0055$)$ and relative $\left(b_{3}=0.0490\right.$ and 0.0425$)$ in 2012/2013 and 2013/2014 seasons, respectively (Table, 2 ).

\section{The cotton aphid, Aphis gossypii (Glov.)}

The mean numbers of $A$. gossypii had positive and insignificant correlation with maximum temperature and minimum temperature $\left(r_{1}=0.3082\right.$ and $r_{2}=0.4207$ ) in $2012 / 2013$ season, respectively, while it was positive and significant $\left(r_{1}=0.6186^{*}\right.$ and $\left.\mathrm{r}_{2}=0.5623^{*}\right)$ in $2013 / 2014$ season, respectively. The correlation coefficient was positive and insignificant between the population density of $A$. gossypii and relative humidity $\left(\mathrm{r}_{3}=0.3071\right.$ and 0.4267$)$ in 2012/2013 and 2013/2014 seasons, respectively (Table, 2). The partial regression between A. gossypii population and maximum temperature, minimum temperature or relative humidity was positive and insignificant $\left(b_{1}=0.0043 \& 0.0225, b_{2}=0.0061 \&\right.$ 0.1500 and $b_{3}=0.0143 \& 0.5410$ in 2012/2013 and 2013/2014 seasons, respectively), Table, (2).

\section{English grain aphid, Sitobion avenae (F.)}

The mean numbers of $S$. avenae had positive and significant correlation with maximum temperature $\left(\mathrm{r}_{1}\right.$ $\left.=0.5629^{*}\right)$ in $2012 / 2013$ season, while it was positive and high significant $\left(r_{1}=0.6250^{* *}\right)$ in $2013 / 2014$ 
season. The relationship between the numbers of $S$. avenae and minimum temperature was positive and significant $\left(r_{2}=0.5263^{*}\right.$ and $0.5106^{*}$ in $2012 / 2013$ and 2013/2104 seasons, respectively). The correlation coefficient was positive and insignificant between the population density of $S$. avenae and relative humidity $\left(r_{3}=0.2661\right)$ in $2012 / 2013$, but it was negative and insignificant $\left(\mathrm{r}_{3}=-0.2653\right)$ in 2013/2014 season, respectively (Table, 2). In the first season, the partial regression was positive and insignificant between $S$. avenae population and maximum and minimum temperature $\left(b_{1}=0.0681\right.$ and $b_{2}=0.0798$, respectively). In the second season, the partial regression was insignificant but positive with maximum temperature $\left(b_{1}=0.0064\right)$ and negative with minimum temperature $\left(b_{2}=-0.0899\right)$. The partial regression was positive and insignificant between $S$. avenae population and relative humidity $\left(b_{3}=0.7562\right.$ and 0.2935 in 2012/2013 and 2013/2014 seasons, respectively), Table, (2).

III. Combined effects of meteorological factors and path analysis

The effect of maximum, minimum temperatures and mean relative humidity on aphid population was estimated by calculating the partial regression analysis (Least square regression equation).

Table 2. Partial regression and simple correlation coefficients between maximum temperature, minimum temperature and relative humidity and total number of aphid species infesting maize, wheat and barley plants at Abo - Hammad district, Sharkia Governorate during 2012/2013 and 2013/2014 seasons

\begin{tabular}{|c|c|c|c|c|c|c|}
\hline \multirow{3}{*}{ Aphid species } & \multicolumn{6}{|c|}{ Simple correlation } \\
\hline & \multicolumn{3}{|c|}{$2012 / 2013$} & \multicolumn{3}{|c|}{$2013 / 2014$} \\
\hline & $\mathbf{r}_{1}$ & $\mathbf{r}_{2}$ & $\mathbf{r}_{3}$ & $\mathbf{r}_{1}$ & $\mathbf{r}_{2}$ & $\mathbf{r}_{3}$ \\
\hline Rhopalosiphum maidis & 0.3140 & 0.2549 & 0.3162 & 0.3130 & 0.3070 & .3033 \\
\hline Rhopalosiphum padi & 0.3156 & $0.5769^{*}$ & 0.3162 & $0.5630^{*}$ & $0.5114^{*}$ & 0.3071 \\
\hline Schizaphis graminum & 0.2638 & 0.2672 & 0.2651 & 0.2661 & -0.0941 & 0.2657 \\
\hline Aphis gossypii & 0.3082 & 0.4207 & 0.3071 & $0.6186^{*}$ & $0.5623^{*}$ & 0.4267 \\
\hline \multirow[t]{2}{*}{ Sitobion avenae } & $0.5629 *$ & $0.5263^{*}$ & 0.2661 & $0.625 * *$ & $0.5106^{*}$ & -0.2653 \\
\hline & \multicolumn{6}{|c|}{ Partial regression } \\
\hline \multirow[t]{2}{*}{ Aphid species } & \multicolumn{3}{|c|}{ 2012/2013 } & \multicolumn{3}{|c|}{$2013 / 2014$} \\
\hline & $\mathbf{b}_{1}$ & $\mathbf{b}_{2}$ & $\mathbf{b}_{3}$ & $\mathbf{b}_{1}$ & $\mathbf{b}_{2}$ & $\mathbf{b}_{3}$ \\
\hline Rhopalosiphum maidis & 2.5980 & 5.4720 & 0.0021 & 3.6450 & 4.1728 & 0.3750 \\
\hline Rhopalosiphum padi & 0.0015 & 0.0021 & 0.0037 & 0.0023 & 0.0014 & 0.0042 \\
\hline Schizaphis graminum & 0.0302 & 0.0182 & 0.0490 & 0.0264 & -0.0055 & 0.0425 \\
\hline Aphis gossypii & 0.0043 & 0.0061 & 0.0143 & 0.02245 & 0.15002 & 0.541 \\
\hline Sitobion avenae & 0.0681 & 0.0798 & 0.7562 & 0.00639 & -0.0899 & 0.2935 \\
\hline
\end{tabular}

$\mathrm{r}_{1}, \mathrm{~b}_{1}=$ correlation coefficients and partial regression between maximum temperature and number of insects, respectively

$\mathrm{r}_{2, \mathrm{~b} 2}=$ correlation coefficients and partial regression between minimum temperature and number of insects, respectively

$r_{3}, b_{3}=$ correlation coefficients and partial regression between relative humidity and number of insects, respectively

The values of explained variance by the three aforementioned meteorological factors showed that the considered factors have played a conspicuous role in detecting the activity of these pests during the seasons of studies (Table, 3 ).

These results indicated that the tested meteorological factors play a great role in regulating the population density of aphid species. Many authors reported similar findings, which greatly correspond with the present results (Hegab, 1997 \& 2001; El-Gindy, $1997 \&$ 2002; Hashem, 1997 \& 2005 and AbdElsamed, 1999 \& 2006).
The method of path coefficient included the independent variable i.e. maximum temperature, minimum temperature and mean relative humidity. Path analysis was practiced in order to find out the relative importance of these variable in contributing numbers of insects Table, (3) presented the relative importance in contributing numbers of insects as recorded in percentage of variation of maximum temperature; minimum temperature and mean relative humidity in 2012/2013 and 2013/2014 seasons. 
Table 3. Explained and unexplained variance and the effects of maximum, minimum temperature and mean relative humidity on the total numbers of aphids infesting maize, wheat and barley plants during 2012/2013 and 2013/2014 seasons at Abo-Hammad, Sharkia, Governorate

\begin{tabular}{lcccc}
\hline \multirow{2}{*}{ Aphid species } & \multicolumn{2}{c}{ Explained variance } & \multicolumn{2}{c}{ Unexplained variance } \\
\cline { 2 - 5 } & $\mathbf{2 0 1 2}$ & $\mathbf{2 0 1 3}$ & $\mathbf{2 0 1 2}$ & $\mathbf{2 0 1 3}$ \\
\hline Rhopalosiphum maidis & 0.2620 & 0.1175 & 0.7380 & 0.8825 \\
Rhopalosiphum padi & 0.3879 & 0.4017 & 0.6103 & 0.5983 \\
Schizaphis graminum & 0.1584 & 0.1992 & 0.8416 & 0.8008 \\
Aphis gossypii & 0.2978 & 0.5599 & 0.7022 & 0.4401 \\
Sitobion avenae & 0.7562 & 0.2935 & 0.2438 & 0.7065 \\
\hline
\end{tabular}

\section{References}

Abd-Alla, K. A. (1985): Studies on Rhopalosiphum maidis at Zagazig region. M.Sc. Thesis, Fac. Agric. Zagazig Univ., $181 \mathrm{pp}$.

Abd-Elsamed, A. A. (1999): Studies on certain piercing sucking insect vectors of plant pathogenic diseases M.Sc. Thesis, Fac. Agric., Zagazig Univ., 176 pp.

Abd-Elsamed, A. A. (2006): Studies on some homopterous insect vectors of plant diseases. Ph.D. Thesis, Fac. Agric., Zagazig Univ., 387 pp.

Abou-Elhagag, G. H. and N. A. Abdel-Hafez (1998): Cereal aphids (Homoptera: Aphididae): Factors affecting their populations on wheat in Upper Egypt, Assiut. J. of Agric. Sciences, 29(3): 241-252.

Akhtar, M. S. and Shahida-Parveen (2002): Studies on population of wheat aphids on wheat crop in New Campus area, Lahore. PunjabUniversity. Journal of Zoology. 17: 14-22.

Blackman, R. L. and V.F. Eastop (2000): Aphids on the World's Crops, Second Edition. John Wiley \& Sons with the Natural History Museum, London. $x+466$ pages, 58 figures, 51 plates.

El-Gindy, M. A. (1997): Studies on certain homopterous insect infesting some vegetable in Dakahlia Governorate. M. Sc. Thesis, Fac. Agric, Zagazig Univ., Egypt, 172 pp.

El-Gindy, M. A. (2002): Studies on certain homopterous insect vectors of plant pathogenic diseases. Ph. D. Thesis, Fac. Agric. Zagazig Univ., 263 pp.

Habib, A. and E. EI-Kady (1961): The Aphididae. Bull. Soc. Ent. Egypt, 45: 1-137.

Hadi B.A. ; K. L. Flanders ; K. I. Bowen .; J. F. Murphy and S. E. Halbert (2011): Species composition of aphid vectors (Hemiptera : Aphididae) of barley yellow dwarf virus and cereal yellow dwarf virus in Alabama and western Florida. J. Econ. Entomol.104(4): 1167 1173.
Hashem, M. S. (1997): Studies on certain insects infesting some vegetable plants in Sharkia Governorate. M. Sc. Thesis, Fac. Agric. Zagazig Univ., 167 pp.

Hashem, M. S. (2005): Studies on certain piercingsucking insects infesting some vegetable crops. Ph.D. Thesis, Fac. Agric. at Moshtohr Zagazig Univ., 294 pp.

Hegab, A. M.; I. M. Kelany and M. M. EIMaghraby (1987): Survey of leafhoppers and planthoppers infesting maize plants by using three sampling techniques in newly reclaimed sandy areas at Salhia district, Egypt. Mina J. Agric. Res. 9 (2): 945-953.

Hegab, Ola I. M. S. (1997): Studies on certain homopterous insects vector of plant pathogenic diseases. M. Sc. Thesis, Fac. Agric. Zagazig Univ., 134 pp.

Hegab, Ola I. M. S. (2001): Studies on certain insect vectors of plant pathogenic agents. Ph.D. of Science. Fac. Agric. Zagazig Univ.

Nassab, A. D. M.; R.A. Mardfar and Y. Raei (2013): Effects of wheat-oilseed rape intercropping and fertilizers on the population density of Sitobion avenae and its natural enemies. International Journal of Biosciences. $3(5): 43-50$.

Muhammad, A.; R. Muhammad; A. Faheem; F. Muhammad and A. Waheed (2004): Population of aphid, (Schizaphis graminum R.) on different varieties/lines of wheat (Triticum aestivum L.). International Journal of Agriculture and Biology. 6(6): 974 - 977.

Costat statistical software (1990): Microcomputer program analysis version 4.20, Co Hort software, Berkely, CA.

Wangal, A. W.; R. T. Plumb and H. F. V. Emden (2000): Effects of sowing date and insecticides on cereal aphid populations and barley yellow dwarf virus on barley in kenya. Journal of Phytopathology. 148(1): 33 - 37 . 


\section{بعض الدراسات الإيكولوجية على أنواع المنْ التي تصيب بعض المحاصيل النجيلية عزت فرج الخياط 1 عزيزة محمد الجنتيري2 1 \\ 2- مركز البحوث الزراعية - معه بحوث وقاية النباتات - الدقى - جيزة}

أجريت هذة الدراسة فى مركز أبوحماد - محافظة الثرقية خلال موسمي 2013/2012-2014/2013 على أنواع المنْ التى تصيب

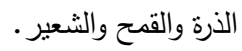
و قد تضمنت الدراسة حصر وتقدير الكثافة العددية لأنواع المن و كذلك تم دراسة الوفرة الموسمية للأنواع السائدة و دراسة تأثير العوامل المناخية (الحرارة العظمى و الحرارة الصغرى و الرطوبة النسبية ) على نشاط وتعداد الحشرات موضع الدراسة. تم أخذ العينات أسبوعياً و جُمِعت حشرات المنْ من محاصيل الذرة، القمح والثُعير بطرق مختلفة وهى كالتالي :

Plant samples أ- العبنات النباتية

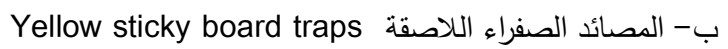
وقد أوضحت الدراسة أن العينات النباتية أفضل طريقة استخدمت لحصر وجمع أفراد المن، أما أنواع المن التى تم حصرها وجمعها من نباتات Rhopalosiphum maidis (Fitch) Rhopalosiphum padi (L.) الذرة ، القمح والثعير فهي: Schizaphis graminum (Rond.)

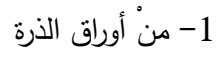
Sitobion avenae (F.) 2- من الثوفان أن إن الثرة Aphis gossypii (Glov.) 3- من القمح القد

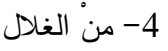

وقد أوضحت الدراسة أن الأنواع الثلاثة الأولى هى الأنواع السائدة على نباتات القمح والثعبر بينما النوع الأول و الثانى و الخامس 5- من القطن هى الأنواع السائدة على نبات الذرة الثامية. أوضحت نتائج دراسة الوفرة الموسمية للأنواع السائدة أن من الذرة سجل على نباتات الذرة قمة نشاط واحدة (1640 و 1250

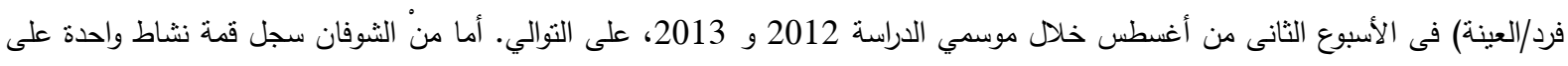
الذرة (978 و 815 فرد/العينة) فى الأسبوع الثالث من أغسطس خلال موسمي الدراسة 2012 و 2013. 2013. وقد سجل من القطن قمة نشاط واحدة

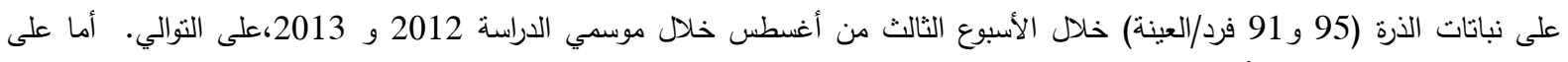
نباتات القمح فقد سجل من الذرة قمة نشاط واحدة (285 و 266 فرد/العينة) خلال الأسبوع الرابع من فبراير خلال موسمي الدراسة

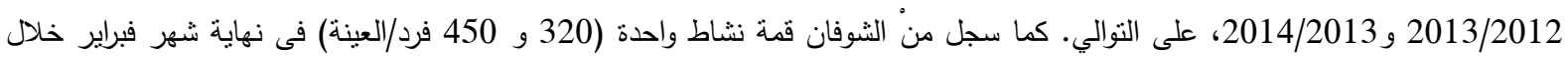

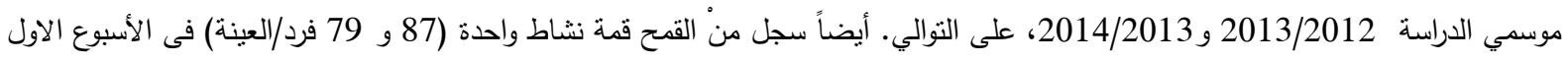

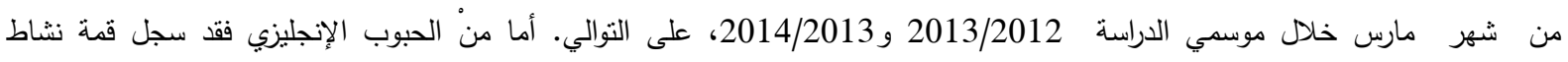
واحدة(199 و 710 فرد/العينة) فى الأسبوع الثانى من أبريل خلال موسمي الدراسة لنباتات الثعير فسجل من الذرة قمة نشاط واحدة (271 و 285 فرد/العينة) فى الأسبوع الثالث والرابع من شهر فبراير خلال موسمي الدراسة

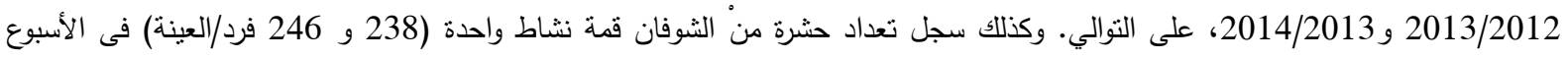
الثالث من فبراير خلال موسمي الدراسة 2013/2012 و 2014/2013، على النوالي. وكذلك سجل من القمح قمة نشاط واحدة (34 و 35 فرد/العينة) فى الأسبوع الثالث والرابع من شهر فبراير خلال موسمي الدراسة 2013/2012 و 2014/2013، على التوالي.

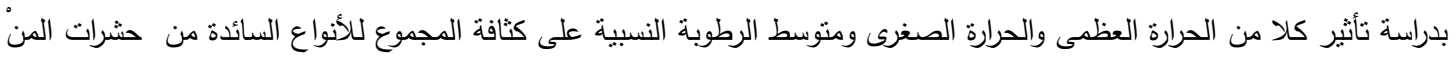
محاصيل الذرة، القمح والثعير خلال موسمي 2013/2012 و 2014/2013 أوضحت النتائج أن كل من درجة الحرارة العظمى ودرجة الحرارة الصغرى و الرطوبة النسبية لهم تأثنر إيجابي أوسلبي وإما معنوي أوغير معنوي على تعداد تلك الحشرات سالفة الذكر. 